\title{
An Uncommon Wealth ... Transforming the Commons With Purpose, for People and Not for Profit!
}

Journal of Management Inquiry $1-6$

(c) The Author(s) 2015

Reprints and permissions:

erepub.com/journalsPermissions.nav DOI: $|0.1177 / 105649261557979|$ mi.sagepub.com

@SAGE

\author{
Deirdre Tedmanson', Caroline Essers ${ }^{2}$, Pascal Dey ${ }^{4}$, \\ and Karen Verduyn ${ }^{3}$
}

\begin{abstract}
The overemphasis on individualism in much normative entrepreneurship discourse belies the powerful role played by local level and communal forms of barter, culturally based collectivist models of organization, social enterprise, and other forms of co-investment. Following Rindova et al., we argue innovation in entrepreneurship can be an emancipatory process with broad change potential to bring about new economic, social, institutional, and cultural environments. New forms of productive social relations and cooperative effort generate new ways of liberating individual and collective existence. However, the dark side of entrepreneurialism also casts its shadow over the pursuit of an idealized commons. Romanticizing forms of collective entrepreneurialism as a means for elevating vulnerable groups may have contrary effects, especially for those already socially and economically marginalized. Theorizing entrepreneurship from a critical perspective, we draw on Laclau's emancipationoppression dualism. We explore the contradictions and potentialities of locally based communal entrepreneurship as expressions of a dynamic tension, which is simultaneously both transformative and exploitative in orientation.
\end{abstract}

\section{Keywords}

entrepreneurship, emancipation, commons, social change, civil society

\section{Considering the Commons}

Today, work and life, production and reproduction are entirely mixed together - they feed on one another. In other words, the material wealth of the world arises through forms of collaboration, of cooperation - and not only through intellectual work: contacts, relationships, exchanges, and desires have become productive. (Negri, 2004, p. 62)

Considering alternatives to mainstream capitalism and the pursuit of interpreting and theorizing new forms of social action and communal entrepreneurship, and new ways of understanding collective economy, is not an altogether new endeavor. Gibson-Graham's (1996; 1997; 2002; 2003; 2006a; 2006b; 2008a; 2008b) passionate envisioning of alternative economics has exhorted us to stretch beyond the confines of market capitalism toward an "ethics of the local" (2003, p. 49) through "socially creative thinking" (2008b, p.1) for over a decade now. Their feminist theorization of a "post-capitalist politics" (Gibson-Graham, 2006b). has posited numerous case studies as examples of how small-scale, locally based enterprise projects can transform communities.

Gibson-Graham, Cameron and Healy (2013) make visible the diverse economies - of household reproduction, volunteer effort, bartering, cooperatives, collectives, and Indigenous exchange for example - more usually subsumed beneath a hegemonic capitalist market discourse as its excluded "other," as "real" economies that are productive, creative, and innovative social places of vibrant growth. Calas, Smircich, and Bourne (2009) similarly deployed feminist political economics to advocate a critical perspective on entrepreneurship that extends boundaries to explore transformative accounts of "entrepreneurship as social change" (p. 552). They ask,

What would happen, theoretically and analytically, if the focus of the literature were reframed from entrepreneurship as an economic activity with possible social change outcomes to entrepreneurship as a social change activity with a variety of possible outcomes (p. 553)?

\footnotetext{
'University of South Australia, Adelaide, Australia

${ }^{2}$ Radboud University, Nijmegen, Netherlands

${ }^{3} \mathrm{VU}$ University Amsterdam, Netherlands

${ }^{4}$ University of St. Gallen, Switzerland

Corresponding Author:

Deirdre Tedmanson, University of South Australia, School of Psychology, Social Work \& Social Policy, G.P.O. Box 24, Adelaide, SA 500I, Australia. Email: deirdre.tedmanson@unisa.edu.au
} 
Rindova, Barry, and Ketchen (2009) also argued for reframing the focus of analysis onto the "emancipatory aspects of entrepreneuring" (p. 478). Hjorth (2013) drew on European social welfare state theory, and inclusive philosophy and traditions, to suggest "... . we need to make room for entrepreneurship as part of society and not simply the economy" (p. 35).

What has become more recently and newly compelling, however, is a realization that any progressive quest for reclaiming entrepreneurship as a social activity, or repositioning economic activity as part of the social world, shaped by political choices and not exogenous forces, belies the myriad of complexities newly emerging in what is now not only a post-modern but also rapidly becoming a post-human world (Braidotti, 2013). The familiar "social" world of community life, collective interactions and what Habermas (1985; 2000) termed shared "communicative space," is itself becoming increasingly fractured, digitalized, fragmented, and commodified. Familiar understandings of the "commons" as shared geographic, intellectual, cultural, knowledge, and/or social space are increasingly challenged by the need for a deeper and more nuanced understanding of the processes, which lead to the production of social capital from a plethora of unfamiliar subjugated collectives and a range of alternative sources of networked emotional, digital, and other diverse cultural capitals across the "nature-culture continuum" (Braidotti, 2013, p. 13). We are no longer just constituents of diverse local communities portrayed as and captured by our economic submission to a monolithic capitalist market but increasingly the producers and consumers of our own subjectivities.

From a critical entrepreneurship perspective, this opens up many new and exciting opportunities. As Jones and Murtola (2012) pointed out, there is communication and knowledge production now occurring globally on a scale and scope that is "artificial or produced, and not produced by one but by many" (p. 640).

However, this tendency also typifies what Hardt and Negri (2009) term capital's predilection to "expropriate cooperation" (p. 140):

Capital is predatory, as the analysts of neoliberalism say, insofar as it seeks to capture and expropriate autonomously produced common wealth (p. 141).

Our pursuit of a critical take on entrepreneurship is fuelled in part by a shared and passionate interest in these paradoxical tendencies of entrepreneuring. On one hand, entrepreneurial behavior can be conformist, assimilationist, and competitive, epitomizing all that is embedded and taken for granted in patriarchal liberal individualism, while on the other hand, entrepreneurship is part of the repertoire of capacities that enables defence of the commons, resistance to dependency, and the resilience of marginalized communities.
The entrepreneurial "spirit" is ironically that which also embodies the sustainable proof that alternative economics, the longevity of models of worker cooperatives, the durability of Indigenous, and other "barefoot" or "micro" community-based enterprises (Imas, Wilson, \& Weston, 2012), the very promise of other worlds, is possible!

\section{Producing in Common}

Although the study of entrepreneurship has largely been dominated by economic discourse, signs of change abound: Concepts such as Indigenous entrepreneurship, communitybased entrepreneurship or enterprising communities more generally, sustainable entrepreneurship, eco-entrepreneurship, and social entrepreneurship more broadly contain the seeds for an altogether different reality (Anderson, Honig \& Peredo, 2006; Steyaert \& Dey, 2010; Tedmanson, Verduyn, Essers \& Gartner, 2012). Issues of emancipation, politics, ethics, caring, solidarity, community are sources of inspiration for drawing out the radical potentiality of entrepreneurship and reflect a willingness to incorporate progressive forms of political theorizing (e.g., Gibson-Graham, 1996, 2006a; 2006b; Adam \& Groves, 2007). Blending theories of entrepreneurship and political theories of (radical) change has yielded many new insights into how entrepreneuring precipitates not only economic but also various forms of social and societal value (Welter, 2011).

An Indigenist take on entrepreneurship combines an approach to processes of production and re/production with a communal epistemology and political ecology that has endured for millennia (Tedmanson, 2014). Sustained over time with dignity and strength, despite generational histories of colonial decimation and dispossession, Indigenous communities globally have maintained continuous local efforts to develop sustainable, strategic, and culturally appropriate ways of production and exchange to meet social and cultural aims, as well as economic ones (Banerjee \& Tedmanson, 2010; Schaper, 2007; Down, 2012; Peredo, Anderson, Galbraith, Honig, \& Dana, 2004).

Indigenous owned and operated cultural tourism ventures, local social enterprises, and environmentally sustainable work "on country" using Indigenous knowledge/s by and for the maintenance of community self-determined lifestyles are enterprising and productive, in ways often little understood and seldom recognized-indeed often undermined or thwarted by the continuum of colonial oppression/s in the neoliberal present (Banerjee \& Tedmanson, 2010). However, Australian Indigenous leader Arabena (2008) argued that a "Universe-referent citizenship" based on Indigenous knowledge and worldviews, has a timely wisdom to offer:

Seeing ourselves as citizens of the Universe would place us in relationships of interdependence and reciprocity as opposed to ones of dominance and exploitation. (p. 2) 
Such powerfully relational empowerment approaches lead us to argue that all interconnected and/or collective entrepreneurial work involves deep shares of what we term relational capital at its core. Relationships are key, and are not only emotional and interactive processes but also ones that are productive of agency and collective will.

Other marginalized groups also are increasingly revealing the creative, interactive, and productive nature of entrepreneuring from the margins. Studies by Ahl and Marlowe (2012), Pio (2005), Essers and Benschop (2007), Essers (2009), Ozkazanc-Pan (2014), Essers and Tedmanson (2014), Peredo et al. (2004), Hjorth (2003, 2005), and Imas et al. (2012), among many others, have sought to "voice" less privileged entrepreneurial subjectivities. These studies highlight the role of entrepreneurial endeavors in contributing to both familial and communal advancement in ways that are generative at multiple levels. They also demonstrate a different form of and approach to generating social and emotional well-being, prosperity, and productivity, as a vital response to community exclusion, which involves forms of social transformations through new creative assemblages that produce innovation well beyond simple material gains (Daskalaki, 2014).

\section{Producing Paradox}

Despite such promise, an evangelical entrepreneurial discourse comprised primarily of the "messianistic script of harmonious social change" (Dey \& Steyaert, 2010) deserves caution. Laclau's dualistic schema reminds us that "the 'dark side' of entrepreneurship represents the flipside of emancipation" (Verduyn, Dey, Tedmanson, \& Essers, 2014, p. 5). We conceive here of entrepreneurship as cutting two ways, comprising emancipation and oppression as forces, which stand in a relationship of constant contest, producing paradoxical tensions. Verduyn and Essers (2013) also argued the discursive view of entrepreneurialism as emancipatory is often an overly romanticized projection. The "happy-endism" and sense of redemption conveyed by many articles dealing with the emancipatory thrust of entrepreneurship can overestimate the extent to which collective entrepreneurship can bring about societal transformation (Blackburn \& Ram, 2007).

Similarly, much research tends to simplify the complexities of globalization, potentially overlooking that the capitalist experience of which we are all part is like a Möbius-strip where the other side is always already included (GilmanOpalsky, 2011). To posit local creative collectives or micro entrepreneurship, for example, as able to generate pristine news spaces of absolute autonomy outside of what Jacques Camatte calls the "despotism of capital" seems a form of denial of the evidence that emancipation is often only a fleeting moment, enclosed or neutralized by the expansive force of the capitalist project. Edwards (2008) pointed out that social entrepreneurship, for example, might end up treating the symptoms rather than the root causes of today's most virulent social and ecological problems. Social entrepreneurship in this context can become a strategic tool in which entrepreneurial modes of self-fashioning become the normative teleology (Dey, 2014).

Discourses of social and communally based entrepreneurship and institutional support for their start-up can help expand the market into areas not previously governed by market logics, thus essentially scripting people's "ideal subjectivity" alongside entrepreneurial virtues and behaviors. As Verduyn and Essers (2013) also pointed out, the positive power and optimism that are attributed to entrepreneurship by institutional actors do not necessarily reflect the lived reality of those who become the objects of discourse.

Caffentzis (2010) even directly argued the commons as well as other cooperative forms of production can easily by "used for capitalist accumulation" (p. 29). Indeed, the mobilization of "community" or "civil society" actors has been acknowledged by neoliberal economists as a key mechanism for saving the capitalist economy from its own demise (Caffentzis, 2010).

Our joint interest, however, remains strongly focused on the micro potentialities for change. Acknowledging Laclau's basis in a utopian envisioning of a better world, our critical perspective orientates to the "micro-manifestations of emancipation as epitomized by entrepreneurship's engagement in localized, everyday struggles and practices of freedom" (Verduyn et al., 2014, p. 101). We remain in pursuit of entrepreneuring as a way of world-making that can be both socially just and socially transformative (Steyaert \& Katz, 2004; Rindova et al., 2009; Tedmanson et al, 2012).

Processes of change which liberate social, cultural, and "relational" capitals and encourage new forms of organization which challenge older fixed hierarchies and models of linear growth, are crucial to resistance (Hardt \&Negri, 2009). Paradoxes and dualisms will always generate creative tensions that are at one and the same time both dialectic and productive.

\section{Considering (Un)Common Futures, in Common}

Future critical work could usefully consider the "micro"/ detailed terrain of how the highly political processes implicated in social enterprise unfold, what tactics are being employed, whose futures are being materialized, and how. One conspicuous and concerning feature about collective forms of entrepreneurship remains how these can be coopted and integrated in subtle and insidious ways into the larger project of "making the world safe for (and not from) neoliberalism" (Caffentzis, 2010, p. 32). Given the increasing fluidity of the present (Deleuze, 1992), the escalating reach of new technological synergies (Braidotti, 2011, 2013), 
and the way social entrepreneurship is at times used to strengthen rather than overthrow the status quo (Dey \& Steyaert, 2012), a critical analysis is needed to monitor if, how, and when forms of "social" entrepreneurship are captured or normalized as ballast against radical change (Hjorth \& Steyart, 2003; Hjorth, 2013). Social transformation is not just another problem-solving exercise but rather the active collectivization of subjectivities, which working in action together subvert the "ideal subject" imaginaries passed down by dominant discourse.

Collective strategies for the renewal of the commons, the development of social entrepreneurial ventures, and the increasing support for local community-based enterprises now span the spectrum between subversion and radical civil action through to compliant substitution for declining government investments in arts, education, health, welfare, and civic well-being. Gibson-Graham (2006a) suggests, however, that social transformation can often begin with a simple refusal to perceive oneself in terms of the hegemonic categories of a capital-centric ideology.

Our obligation here is not only epistemological in nature but inherently ontological. It is through collectivist, participatory, and engaged action that marginalized populations, who have had little or no say in how the social reality around them is designed, used, and exploited can express their voices (Steyaert, 2011; Tedmanson \& Banerjee, 2009). By "changing the social through activist, spatial and minor practices" (Steyaert \& Dey, 2010, p. 234) together, we can demonstrate our hope in the potential of locally generated and co-enacted communal futures to build our uncommon wealth.

\section{Declaration of Conflicting Interests}

The author(s) declared no potential conflicts of interest with respect to the research, authorship, and/or publication of this article.

\section{Funding}

The author(s) received no financial support for the research, authorship, and/or publication of this article.

\section{References}

Adam, B., \& Groves, C. (2007). Future matters: Action, knowledge, ethics. Leiden, The Netherlands: Brill.

Ahl, H., \& Marlowe, S. (2012). Exploring the dynamics of gender, feminism and entrepreneurship, advancing debate to escape a dead end? Organization, 19, 543-562.

Anderson, R., Honig, B., \& Peredo, A. (2006). Communities in the global economy: Where social and indigenous entrepreneurship meet. Cheltenham, UK: Edward Elgar.

Arabena, K. (2008, December). Indigenous epistemology and wellbeing: Universe referent citizenship (AIATSIS Discussion Paper, No. 22). Canberra: Australian Institute of Aboriginal and Torres Strait Islander Studies.

Banerjee, B., \& Tedmanson, D. (2010). Grass burning under our feet: Indigenous enterprise development in a political economy of whiteness. Management Learning, 41, 147-165.
Blackburn, R., \& Ram, M. (2007). Fix or fixation? The contributions and limitations of entrepreneurship and small firms to combating social exclusion. Entrepreneurship \& Regional Development, 18, 73-89.

Braidotti, R. (2011). Nomadic subjects. New York, NY: Columbia University Press.

Braidotti, R. (2013). The posthuman. Cambridge, UK: Polity.

Caffentzis, G. (2010). The future of "The Commons": Neoliberalism's "plan B" or the original disaccumulation of capital? New Formations, 69, 23-41.

Calas, M., Smircich, L., \& Bourne, K. (2009). Extending the boundaries: Reframing "entrepreneurship as social change" through feminist perspectives. Academy of Management Review, 34, 552-569.

Daskalaki, M. (2014). Mobility in urban social events: Towards organizational transvergence. Culture and Organization, 20, 215-231.

Deleuze, G. (1992, Winter). Postscript on control societies. October, 59, 3-7.

Dey, P. (2014). Governing the social through "social entrepreneurship": A Foucauldian view of the "art of governing" in advanced liberalism. In H. Douglas \& S. Grant (Eds.), Social Innovation and Social Entrepreneurship: Context and Theories (pp. 155-172). Prahran, Victoria: Tilde Publishing.

Dey, P., \& Steyaert, C. (2010). The politics of narrating social entrepreneurship. Journal of Enterprising Communities: People and Places in the Global Economy, 4, 85-108.

Dey, P., \& Steyaert, C. (2012). Social entrepreneurship: Critique and the radical enactment of the social. Social Enterprise Journal, 8, 90-107.

Down, S. (2012). Evaluating the impacts of government policy through the long view of history. Entrepreneurship \& Regional Development, 24, 619-639.

Edwards, M. (2008). Just another emperor? The myth sand realities of philanthrocapitalism. New York, NY: Demos.

Essers, C. (2009). Reflections on the narrative approach: Dilemmas of power, emotions and social location while constructing lifestories. Organization, 16, 163-181.

Essers, C., \& Benschop, Y. (2007). Enterprising identities: Female entrepreneurs of Moroccan and Turkish origin in the Netherlands. Organization Studies, 28, 49-69.

Essers, C., \& Tedmanson, D. (2014). Upsetting "others" in the Netherlands: Narratives of Muslim Turkish migrant businesswomen at the crossroads of ethnicity, gender and religion. Gender, Work \& Organization, 21, 353-367.

Gibson-Graham, J. K. (1996). The end of capitalism (as we knew it): A feminist critique of political economy. Oxford, UK: Blackwell.

Gibson-Graham, J. K. (1997). Postmodern becomings: From the space of form to the space of potentiality. In G. Benko \& U. Strohmayer (Eds.), Space and social theory: Interpreting modernity and postmodernity (pp. 306-323). Oxford, UK: Blackwell.

Gibson-Graham, J. K. (2001). Re/presenting class. Durham, NC: Duke University Press.

Gibson-Graham, J. K. (2002). Beyond global vs. local: Economic politics outside the binary frame. In A. Herod \& M. Wright (Eds.), Placing Scale (pp. 25-60). Oxford, UK: Blackwell. 
Gibson-Graham, J. K. (2003). An ethics of the local. Rethinking Marxism: A Journal of Economics, Culture \& Society, 15, 49-74.

Gibson-Graham, J. K. (2006a). The end of capitalism (as we knew it): A feminist critique of political economy:Introduction to the New Edition: Ten Years On. Minneapolois, MN: First University of Minnesota Press.

Gibson-Graham, J. K. (2006b). A postcapitalist politics. Minneapolis, MN: University of Minnesota Press.

Gibson-Graham, J. K. (2008a). Diverse economies: Performative practices for 'other worlds'. Progress in Human Geography, $32(5), 1-20$.

Gibson-Graham, J. K. (2008b). Socially creative thinking or how experimental thinking creates 'other worlds'. Retrieved from http://www.communityeconomies.org/people/jk-gibsongraham

Gibson-Graham, J. K., Caemron, J., \& Healy, S. (2013). Take back the economy: An ethical guide for transforming communities. Minneapolis, MN: University of Minnesota Press.

Gilman-Opalsky, R. (2011). Spectacular capitalism: Guy debord and the practice of radical philosophy. London, England: Minor Compositions.

Habermas, J. (1985). The theory of communicative action: Volume 2: Lifeworld and system: A critique of functionalist reason. Boston, MA: Beacon Press.

Habermas, J. (2000). On the pragmatics of social interaction preliminary studies in the theory of communicative action. Cambridge, MA: MIT Press.

Hardt, M., \& Negri, A. (2009). Commonwealth. Cambridge, MA: Harvard University Press.

Hjorth, D. (2003). Rewriting entrepreneurship: For a new perspective on organisational creativity. Malmo, Sweden: Liber.

Hjorth, D. (2005). Organizational entrepreneurship: With de Certeau on creating heterotopias (or spaces for play). Journal of Management Inquiry, 14, 386-398.

Hjorth, D. (2013). Public entrepreneurship: Desiring social change, creating sociality. Entrepreneurship \& Regional Development, 25, 34-51.

Hjorth, D., \& Steyaert, C. (2003). Entrepreneurship beyond (a new) economy: Creative swarms and pathological zones. In C. Steyaert \& D. Hjorth (Eds.), New movements in entrepreneurship (pp. 286-303). Cheltenham, UK: Edward Elgar.

Imas, M., Wilson, N., \& Weston, A. (2012). Barefoot entrepreneurs. Organization, 19, 563-585.

Jones, C., \& Murtola, A.-M. (2012). Entrepreneurship and expropriation. Organization, 19, 635-655.

Negri, A. (2004). Negri on Negri (M. B. DeBevoise, Trans.). London, England: Routledge.

Ozkazanc-Pan, B. (2014). Postcolonial feminist analysis of high-technology entrepreneuring. International Journal of Entrepreneurial Behaviour \& Research, 20(2), 155-172.

Peredo, A., Anderson, R., Galbraith, C., Honig, B., \& Dana, L. (2004). Towards a theory of indigenous entrepreneurship. International Journal of Entrepreneurship \& Small Business, $1,1-20$.

Pio, E. (2005). Knotted ends: Working lives of Indian women migrants in New Zealand. Human Relations, 58, 1277-1300.
Rindova, V., Barry, D., \& Ketchen, D. J. (2009). Entrepreneuring as emancipation. Academy of Management Review, 34, 477-491.

Schaper, M. (2007). Aboriginal and Torres Strait Islander entrepreneurship in Australia: Looking forward, looking back. In L. P. Dana \& R. B. Anderson (Eds.), International Handbook of Research on Indigenous Entrepreneurship (pp. 526-535). Cheltenham, UK: Edward Elgar.

Steyaert, C. (2011). Entrepreneurship as in(ter)vention: Reconsidering the conceptual politics of method in entrepreneurship studies. Entrepreneurship\& Regional Development, 23, 77-88.

Steyaert, C., \& Dey, P. (2010). Nine verbs to keep the social entrepreneurship research agenda "dangerous." The Journal of Social Entrepreneurship, 1, 231-254.

Steyaert, C., \& Katz, J. (2004). Reclaiming the space of entrepreneurship in society: Geographical, discursive and social dimensions. Entrepreneurship \& Regional Development, 16, 179-196.

Tedmanson, D. (2014). Indigenous social entrepreneurship: Resilience and renewal. In H. Douglas \& S. Grant (Eds.), Social Entrepreneurship and Enterprise: Concepts in Context (pp. 173-193). Prahran, Victoria: TildePublishing.

Tedmanson, D., \& Banerjee, S. B. (2009). Participatory action research. In A, Mills, G. Durepos, \& E. Wiebe (Eds.), Encyclopedia of case study research. (pp.656-659). London, England: SAGE.

Tedmanson, D., Verduyn, K., Essers, C., \& Gartner, W. B. (2012). Critical perspectives in entrepreneurship research. Organization, 19, 531-541.

Verduyn, K., Dey, P., Tedmanson, D., \& Essers, C. (2014). Emancipation and/or oppression? Conceptualizing dimensions. International Journal of Entrepreneurial Behaviour \& Research, 20, 98-107.

Verduyn, K., \& Essers, C. (2013). Entrepreneuring as emancipation? Questioning the entrepreneurship ideology. Entrepreneurship \& Regional Development, 25, 612-630.

Welter, F. (2011). Contextualizing entrepreneurship: Conceptual challenges and ways forward. Entrepreneurship Theory and Practice, 35, 165-184.

\section{Author Biographies}

Deirdre Tedmanson is program director for social sciences in the School of Psychology, Social Work and Social Policy at the University of South Australia and a member of its Centre for Social Change. Her research interests include Indigenous entrepreneurship, socio-cultural and gendered aspects of entrepreneurship, critical management studies, post-colonial theory, the political economy of violence and power, Indigenous sovereignty and rights, environmental and social justice, and participatory action research methodologies. She has published in Organization; Gender, Work and Organization; the Management Learning Journal; International Journal of Entrepreneurial Behaviour \& Research; and Organization Studies.

Caroline Essers is associate professor of entrepreneurship at VU University, Amsterdam, and assistant professor of strategic human resource management at Faculty of Management, Radboud University, Nijmegen. Her research focuses on the social dynamics of entrepreneurship, such as identity constructions of (female 
migrant) entrepreneurs. She uses diverse perspectives in her research on entrepreneurship, such as post-colonial feminist theory and social constructivist approaches such as the narrative/life-story approach. Her work has been published in Organization Studies, Organization, Human Relations, Gender, Work and Organization, British Journal of Management, Entrepreneurship and Regional Development, and International Journal of Entrepreneurial Behaviour \& Research. She is a board member of the Entrepreneurship Studies Network and an associate editor for Gender, Work and Organization.

Pascal Dey is a senior research fellow at the Institute for Business Ethics, University of St. Gallen (Switzerland). His research deals with the intersection of (social) entrepreneurship and issues such as discourse, power, resistance, and identity. His most recent research is informed by the work of Derrida, Agamben, and Ricoeur, and reflects (social) entrepreneurship from the vantage point of the monstrous, destitution, and hermeneutic imagination.

Karen Verduyn is senior lecturer at the Faculty of Economics \& Business Administration of VU University, Amsterdam, and programme director of the Amsterdam (joint) MSc in Entrepreneurship. Her research projects revolve around understanding the complexities of entrepreneurial everyday life. She has published in journals such as the International Review of Entrepreneurship, the Journal of Enterprising Communities, Entrepreneurship and Regional Development, and Organization. She is a board member of the Entrepreneurship Studies Network and the International Journal of Entrepreneurship and Small Business. 